Jurnal Teknologi, 45(A) Dis. 2006: 43-53

(C) Universiti Teknologi Malaysia

\title{
THERMOGRAVIMETRIC AND THERMOCHEMICAL STUDIES OF MALAYSIAN OIL PALM SHELL WASTE
}

\author{
AHMAD HUSSAIN ${ }^{1}$, FARID NASIR ANI ${ }^{2}$, AMER NORDIN DARUS $^{3} \&$ \\ ZAINAL AHMED ${ }^{4}$
}

\begin{abstract}
Recently, owing to environmental and economic considerations, interest in utilizing biomass for the production of energy and chemicals is increasing. Palm oil shell wastes are one of the main agriculture waste in Malaysia. Pyrolysis is one of the most promising thermochemical techniques for recovering energy from biomass. Pyrolysis of oil-palm shell waste was first carried out using thermogravimetric analysis (TGA). The effects of heating rate on the pyrolytic properties were investigated. The kinetic parameters have also been determined using integral method. This paper also describes the experimental results from a bench-scale circulating fluidized-bed (CFB) test rig, installed at SIRIM Berhad, Shah Alam, suitable for gasification and combustion experiments using different biomass materials. The purpose of the tests was to investigate the suitability of the selected fuels for energy production using Circulating Fluidised Bed Combustor (CFBC) while taking care of the flue gas emissions. Operating parameters (such as temperature, type of biomass, feeding rate, heating rate, pressure, primary air and reactor configuration) are believed to influence significantly the pyrolysis of a biomass. Temperature is one of the most important operating variants so the experimental studies were done to investigate the influence of temperature on pyrolysis. the concentrations of $\mathrm{CO}, \mathrm{NO}_{\mathrm{x}}$ and $\mathrm{CO}_{2}$ in the flue gas were measured. The combustion performances were evaluated by varying the primary gas flow through the CFBC tubular furnace. the emission of $\mathrm{NO}_{\mathrm{x}}$ ranged from 38-75 ppm while the $\mathrm{CO}$ emissions were high for higher primary air flow rates.
\end{abstract}

Key words: biomass, emissions, kinetic parameters, oil palm shell waste, pyrolysis, TGA, thermochemical

\begin{abstract}
Abstrak. Baru-baru ini, dengan pertimbangan ke atas alam persekitaran dan ekonomik, minat terhadap penggunaan biojisim untuk penghasilan tenaga dan bahan kimia semakin meningkat. Tempurung kelapa sawit merupakan salah satu bahan buangan utama di Malaysia. Pirolisis adalah salah satu teknik termo-kimia yang mempunyai harapan untuk penghasilan tenaga daripada biojisim. Dalam kajian awal ini, proses pirolisis dikenakan ke atas tempurung kelapa sawit dengan menggunakan analisis termogravimetrik (TGA). Kesan kadar pemanasan ke atas sifat pirolisis telah dikaji. Parameter kinetik juga telah dikenal pasti dengan menggunakan kaedah kamiran. Kertas kerja ini juga menerangkan keputusan uji kaji dari sebuah radas skala kecil lapisan terbendalir pengedaran semula(CFB), yang terletak di SIRIM
\end{abstract}

${ }^{1-4}$ Faculty of Mechanical Engineering, Universiti Teknologi Malaysia, 81310, Skudai, Johor, Malaysia. Corresponding author details': Phone: 607-5534785 Fax: 607-5566159 E-mail: ahmadutm@gmail.com 
Berhad, Shah Alam, yang mana sesuai untuk uji kaji penggasan dan pembakaran pelbagai bahan biojisim. Objektif kajian ini adalah untuk mengkaji kesesuaian bahan bakar yang terpilih untuk penghasilan tenaga dengan menggunakan CFBC dalam masa yang sama mengambil berat terhadap penghasilan gas emisi. Parameter operasi (seperti suhu, jenis biojisim, kadar suapan, kadar pemanasan, tekanan, suapan udara utama dan konfigurasi reaktor) adalah dipercayai mempengaruhi secara langsung kepada proses pirolisis biomas. Suhu merupakan salah satu pemboleh ubah yang penting, maka dalam kajian ini telah dibuat untuk mengkaji kesan suhu terhadap proses pirolisis. Kandungan $\mathrm{CO}, \mathrm{NO}_{\mathrm{x}}$ dan $\mathrm{CO}_{2}$ dalam gas emisi telah diukur. Prestasi pembakaran telah dikaji dengan mengubahkan kadar aliran udara utama masuk ke dalam kebuk pembakaran CFBC. Bahan emisi $\mathrm{NO}_{\mathrm{x}}$ didapati dalam julat 38 ke 75 ppm manakala bahan emisi CO telah didapati tinggi pada kemasukan kadar aliran udara utama yang tinggi.

Kata kunci: biojisim, emisi, parameter kinetik, tempurung kelapa sawit, pirolisis, TGA, termo-kimia

\subsection{INTRODUCTION}

Palm oil and its liquid fraction, palm olein, are consumed worldwide as cooking oils and constituents of margarine and shortening. During oil palm planting and processing, a large amount of solid wastes such as palm trunks, palm fronds, empty bunches and plam shell waste are generated. Malaysia as being the largest producer of palm oil in the world, generates a significant amount of oil palm wastes. In January 2006 her production of palm oil is about 14.96 millions tons and the total soild wastes generated by this industry has amounted to more than 3.96 millions tons [1]. For every $100 \mathrm{~kg}$ of crude palm oil produced during the oil palm milling process, $52 \mathrm{~kg}$ fiber, $22 \mathrm{~kg}$ shell and $85 \mathrm{~kg}$ empty fruit bunch are generated. There are more than 350 palm oil mills operating in the country. Each plant is equipped with at least a boiler and two incinerators. Palm oil mills are a self sufficient industry as far as energy utilization is concerned. The palm fibers and shells generated as the waste product by the industry are used as boiler fuel in the mill $[2,3]$.

Biomass, as a fuel, is characterized by high moisture and volatile content, low bulk density, low specific energy and normally low ash content. Some properties of biomass fuel are shown in Tables 1 and 2 and they are compared with palm shell [4].

Palm shell waste are generated from oil palm milling process. Fresh fruit bunches contain (on fresh weight) about 27\% palm oil, 6 - 7\% kernel, $14-15 \%$ fiber, $6-7 \%$ shell and 23\% empty fruit bunch material (EFB). The energy content of the palm shell varies according to the moisture, residual oil content and its high specific energy content which is of interest in comparision with the oil palm fibers or EFB. Oil palm shell contains around $67-80 \%$ of volatile matter compared with $40 \%$ to that of coal.

Amongst the thermochemical conversion processes (e.g., pyrolysis, gasification and combustion), pyrolytic process is recognized as the most promising one 
Table 1 Proximate analysis of palm shell waste and rice husks

\begin{tabular}{ccccc}
\hline & \multicolumn{4}{c}{ Proximate analysis \% } \\
\cline { 2 - 5 } Solid waste & Moisture & Volatile & Fixed carbon & Ash \\
\hline Palm shell & 9.7 & 67 & 21.2 & 2.1 \\
Rice husks & 12.0 & 52.4 & 17.1 & 18.5 \\
\hline
\end{tabular}

Table 2 Ultimate analysis of palm shells and rice husks

\begin{tabular}{|c|c|c|c|c|c|c|}
\hline \multirow[t]{2}{*}{ Solid waste } & \multicolumn{5}{|c|}{ Ultimate analysis \% } & \multirow{2}{*}{$\begin{array}{c}\text { GCV } \\
\text { MJ/kg }\end{array}$} \\
\hline & $\mathrm{C}$ & $\mathbf{H}$ & $\mathbf{N}$ & $\mathrm{O}$ & $\mathbf{S}$ & \\
\hline Palm shells & 47.62 & 6.2 & 0.7 & 43.38 & - & 19.1 \\
\hline Rice husks & $38.2-55.8$ & $0.2-0.31$ & $1.7-1.9$ & $29.9-31.7$ & $0.07-0.12$ & $12.12-19.0$ \\
\hline
\end{tabular}

since it can be used either as an independent process for fuels and other valuable chemical products or an initial step to gasification or combustion $[5,6]$. Development of proper thermochemical conversion processes for oil-palm solid wastes and design and operation of related equipment require the determination of kinetic parameters (i.e., activation energy, frequency factor and reaction order) of the pyrolytic process and a detailed understanding of the pyrolytic mechanism itself.

In this paper, pyrolysis of palm shell was carried out using thermogravimetric analysis (TGA). The effects of raw material particle size, pyrolytic temperature and heating rate on the pyrolytic properties (for example, the shape of thermograms) were investigated to determine the main factor of the pyrolytic process.

The oil-palm shell was obtained from a palm oil mill in Kulai, Malaysia. As received palm shells were dried to remove free moisture absorbed during land dumping. The pre-dried samples were crushed and sieved to several size fractions. The pyrolysis of palm shell was carried out using a thermogravimetric analyzer (Perkins Elmer Pyris TGA-7). Approximately, $20 \mathrm{mg}$ sample was placed in an aluminum pan. The furnace was heated from ambient temperature to a programmed temperature of $989^{\circ} \mathrm{C}$ at constant heating rates of 25 and $80^{\circ} \mathrm{C} /$ min. Purified nitrogen (99.9995\% purity) at a constant flow rate was used as the purge gas to provide an inert atmosphere for pyrolysis and to remove any gaseous and condensable products evolved, thus minimizing any secondary 
vapor-phase interactions. The sample was heated by both radiation from the furnace wall and convection of the purge-gas rushing through the furnace chamber. The sample weight was measured continuously by a microbalance as a function of time or temperature.

The experimental thermo chemical study of distinct biomass fuels, namely, oil palm shell waste was also done in a circulating fluidized-bed combustor (CFBC) using alumina particles as inert material. The main objectives of this work were to study formation and reduction of the major gaseous pollutants ( $\mathrm{CO}$ and $\mathrm{NO}$ ) in the CFBC when firing selected biomass fuels, and to see the combustion performance when fired under different operating conditions.

\subsection{EXPERIMENTAL TEST RIG}

The experiments were carried out at SIRIM Berhad, Shah Alam in Malaysia. The system was developed by JFE, Japan under a joint venture programme between the Japanese government through NEDO/METI. The experimental apparatus consists of a circulating fluidized bed type experimental gasifier, experimental sample supplying unit, secondary combustion furnace, gas cooler, dust collector, blower and control panel. A schematic diagram of the test rig is shown in Figure 1.

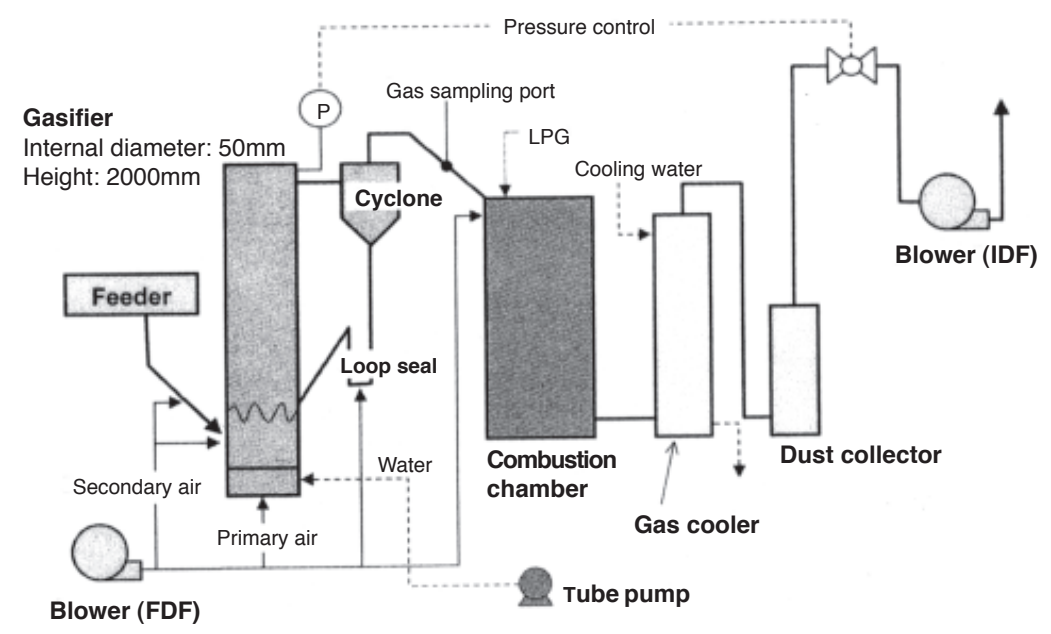

Figure 1 Layout of the experimental CFB gasifier at SIRIM

The fluidizing air was supplied from the bottom and the circulating alumina particles were separated from air by the cyclone and the particles returned through the loop seal on the downstream side of the furnace. The gasifier is 
provided with three external electric heaters (upper, center and lower), which enable to control the temperature in the gasifier. A heater is installed also on the air supply line to preheat air.

A sampling port is provided in the middle of the duct. For monitoring the gasification condition, the concentrations of $\mathrm{CO}, \mathrm{CO}_{2}$ and $\mathrm{O}_{2}$ in the produced gas were measured with a gas analyzer. Biomass sample to be combusted is supplied to the gasifier through the screw feeder and rotary valve.

The secondary combustion chamber is designed to completely burn the combustible gases, such as $\mathrm{CO}$ and $\mathrm{H}_{2}$ contained in the gas produced by gasification. The mixture of the produced gas and air is burnt by a constantly burning LPG burner. The gas cooler after the secondary combustion furnace cools the exhaust combustion gas with cooling water to protect the equipment on the downstream side. However, in this paper the combustible gases were not burned using LPG rather they were discharged through the stack. However, the gases were monitored for the emissions.

The temperatures at various locations in the CFB rig were continuously monitored and recorded using Yokogawa Hybrid Recorder (HR 1300). The furnace pressure, supply airflow rate were also monitored. The concentrations of emission gases $\mathrm{CO}, \mathrm{CO}_{2}$ and $\mathrm{O}_{2}$ contained in the produced gas were also monitored and recorded using calibrated Madur Flue Gas Analyzer (GA-40 plus). The resolution for measurement of $\mathrm{O}_{2}$ and $\mathrm{CO}_{2}$ was $0.01 \%$. The resolution for the measurement of $\mathrm{CO}$ and $\mathrm{NO}$ was $1 \mathrm{ppm}$.

Formation of the circulating fluidized bed was observed by monitoring the change in the temperature of the loop seal. It takes about 3-4 hours before the CFB attains the presets temperatures. The presets temperatures were selected using the thermogravimetric analysis (TGA) showing the devolatization behaviour. After the CFBC temperature reached the specified temperatures, constant feeding of biomass could be started, and the in-furnace temperature and the gas composition $\left(\mathrm{CO}, \mathrm{CO}_{2}\right.$ and $\left.\mathrm{O}_{2}\right)$ were needed to be monitored. After the temperatures stabilized, the primary airflow rate of the fluidizing air was varied and produced gas was analyzed from the sample.

\subsection{DETERMINATION OF KINETIC PARAMETERS}

Thermogravimetric data is used in characterizing the oil as well as in investigating the thermodynamics and kinetics of the reaction and transitions that results from the application to oil samples. Currently several methods are available in the literature that can be used to calculate kinetic parameters [7].

$$
\frac{d \alpha}{d t}=A e^{-E / R T}(1-\alpha)^{n}
$$


where $A\left(\mathrm{~min}^{-1}\right)$ is the frequency or pre-exponential factor of the pyrolytic process, $E(\mathrm{~J} / \mathrm{mol} \mathrm{K})$ is the activation energy of the pyrolytic process, $R(\mathrm{~J} / \mathrm{mol}$ $\mathrm{K})$ is the universal gas constant, $T(\mathrm{~K})$ is the absolute temperature, $n$ is the order of reaction, $t$ is the time, and $\alpha$ is the fraction of reactant decomposed at time $\mathrm{t}$ (min). The fractional reaction $\alpha$ is defined in ter

$$
\alpha=\frac{w_{0}-w}{w_{0}-w_{f}}
$$

Where $w_{0}$, $w$ and $w_{f}$ are the initial, actual and final weights $(\mathrm{mg})$ of the sample, respectively. For constant heating rate $\beta(\beta=d t / d t)$. Equation (1) can be expressed by the following equation:

$$
\frac{d \alpha}{d T}=\frac{A}{\beta} e^{-E / R T}(1-\alpha)^{n}
$$

Rearranging and integrating Equation (3), the following expression can be obtained:

$$
\frac{1-(1-\alpha)^{1-n}}{1-n}=\frac{A}{\beta} \int_{0}^{T} e^{-E / R T} d T
$$

Since $\int e^{-E / R T} d T$ has no exact integral, $e^{-E / R T}$ can be expressed as an asymptotic series and integrated, with the higher -order terms ignored.

$$
\frac{1-(1-\alpha)^{1-n}}{1-n}=\frac{A R T^{2}}{\beta E}\left[1-\frac{2 R T}{E}\right] e^{-E / R T}
$$

Expressing Equation (5) in logarithmic form yields

$$
\ln \left[\frac{1-(1-\alpha)^{1-n}}{T^{2}(1-n)}\right]=\ln \left[\frac{A R}{\beta E}\left[1-\frac{2 R T}{E}\right]\right]-\frac{E}{R T}(\text { for } n \neq 1)
$$

If $2 R T / E \ll 1$ is assumed, Equation (6) becomes

$$
\ln \left[\frac{1-(1-\alpha)^{1-n}}{T^{2}(1-n)}\right]=\ln \left[\frac{A R}{\beta E}\right]-\frac{E}{R T}(\text { for } n \neq 1)
$$


If $n=1$, the following equation can be used

$$
\ln \left[-\frac{\ln (1-\alpha)}{T^{2}}\right]=\ln \left[\frac{A R}{\beta E}\right]-\frac{E}{R T}(\text { for } n=1)
$$

Thus, a plot of

$$
\ln \left[\frac{1-(1-\alpha)^{1-n}}{T^{2}(1-n)}\right] \text { versus } \frac{1}{T}(\text { for } n \neq 1)
$$

or

$$
\ln \left[-\frac{\ln (1-\alpha)}{T^{2}}\right] \text { versus } \frac{1}{T}(\text { for } n \neq 1)
$$

results in a straight line of slope $-E / R$ for the proper value of $n$. The criterion used for the acceptable values of $E$ and $A$ is that the final value of $n$ should yield the values of $E$ whose linear correlation coefficient are the best.

\subsection{RESULTS AND DISCUSSION}

Figure 2 shows the residual weight fractions measured by TGA for 300 microns palm shell powder undergoing pyrolysis at heating rates of $25 \& 80^{\circ} \mathrm{C} / \mathrm{min}$. The sample weight was measured continuously by a microbalance in TGA as a function of time or temperature. The heating rates were chosen as to represent the temperature changes which usually occurs in fluidized beds during slow and rapid burning. It showed a significant weight loss, indicating the occurrence of the main decomposition. At the beginning the combustion is incomplete so $\mathrm{CO}_{2}$ and $\mathrm{CO}$ were released as the main gaseous products and during the main decomposition period, a large amount of gaseous products such as $\mathrm{CO}_{2}, \mathrm{CO}$, $\mathrm{H}_{2}$ and hydrocarbons (i.e. $\mathrm{CH}_{4} ; \mathrm{C}_{2} \mathrm{H}_{4} ; \mathrm{C}_{2} \mathrm{H}_{6}$ ) were released, resulting in a significant weight loss. In Figure 3, the main decomposition was essentially completed by an elapsed duration of $9 \mathrm{~min}$ and $24 \mathrm{~min}$ for heating rates of 80 and $25^{\circ} \mathrm{C} / \mathrm{min}$ respectively. Figure 2 shows the residual weight fractions for pyrolysis of palm shells at heating rates of 25 and $80^{\circ} \mathrm{C} / \mathrm{min}$. It could be seen that there is an obvious lateral shift in the thermograms for different heating rates. In addition, there is an effect of heating rate on the total weight loss. As 
the heating rate was increased, a faster pyrolytic reaction occurred, resulting in higher pyrolytic conversion to volatile species. From Figure 3, it can be inferred that the pyrolysis of oil palm shell waste is pure reaction kinetics controlled, which is highly dependent on the reaction temperature. It is controlled by both heat transfer and chemical reaction. For a lower heating rate, a relatively lower pyrolysis rate was observed.

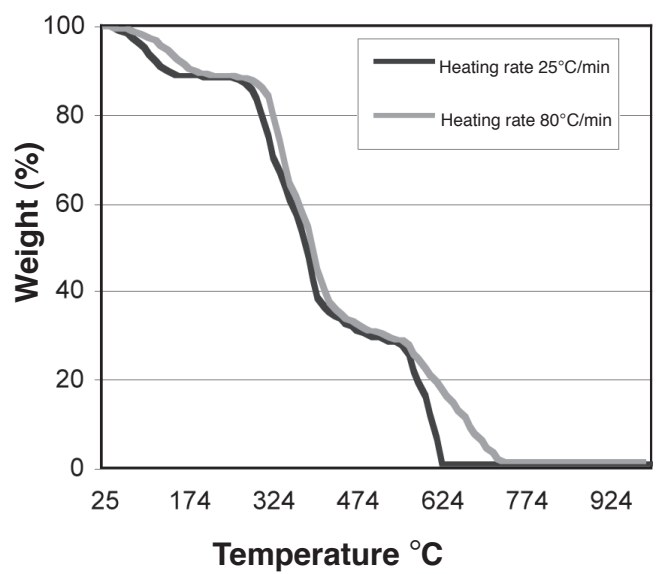

Figure 2 TGA analysis of weight loss $(\%)$ for different heating rates

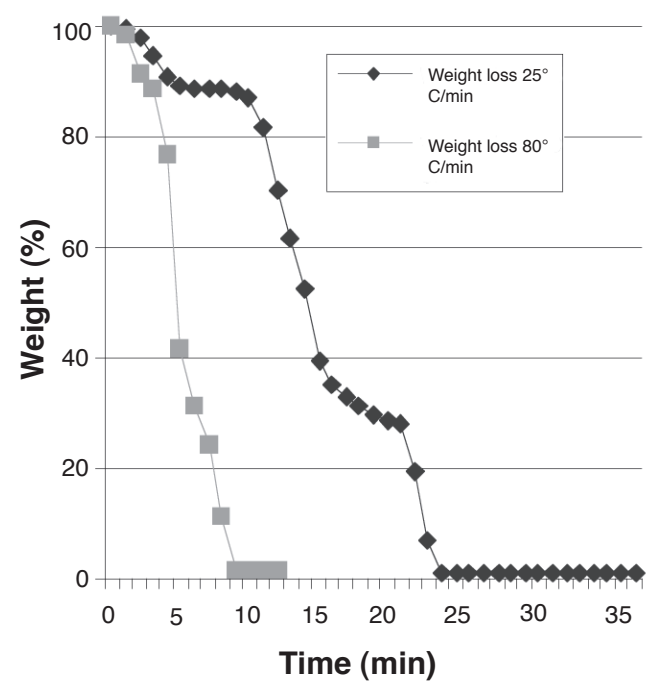

Figure 3 TGA analysis of weight loss (\%) for different heating rates 
Using data from the pyrolysis thermograms (Figure 2), the kinetic parameters, the activation energy $(E)$ and the frequency factor $(A)$, were estimated using Figure 4 with high correlation coefficients (all above 0.94) and listed in Table 3. For all the heating rates, the order of reaction was first-order reaction mechanism for the pyrolysis of palm shells. As the heating rate was increased, the activation energy changed a bit but the frequency factor was dependent on heating rate, increasing progressively from $6.8 \times 10^{3}$ to $6.2 \times 104 \mathrm{~s}^{-1}$. This suggested that the higher the heating rate, the easier and faster would be the pyrolytic reaction. These parameters can be used to predict the time-conversion profiles for the pyrolytic process of different heating rates.

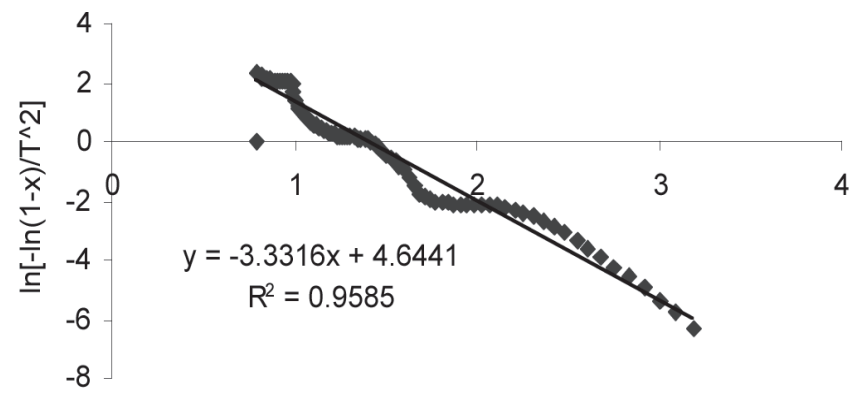

$1000 / T$

Figure 4 Kinetic plot for a heating rate of $80^{\circ} \mathrm{C} / \mathrm{min}$

Table 3 Kinetic Parameters for the pyrolysis of palm shells

\begin{tabular}{ccc}
\hline $\begin{array}{c}\text { Heating } \\
\text { rate }\end{array}$ & $\begin{array}{c}\text { Activation energy } \\
(\mathbf{k J} / \mathbf{m o l e})\end{array}$ & $\begin{array}{c}\text { Frequency factor } \\
\left(\mathbf{s e c}^{-1}\right)\end{array}$ \\
\hline $25^{\circ} \mathrm{C} / \mathrm{min}$ & 26.16 & $6.8 \times 10^{3}$ \\
$80^{\circ} \mathrm{C} / \mathrm{min}$ & 28.01 & $6.2 \times 10^{4}$ \\
\hline
\end{tabular}

The thermochemical studies of palm shell waste of 212-300 microns particles were also carried out in the CFB test rig at SIRIM Berhad. It was found that the palm shell particles were too small and they were easily pushed by the screw feeder even at a low rpm. This caused a heavy flow of fine palm shell particles in the furnace.

The temperature at the top of the CFB increased rapidly as the feeding started and reached to about $709^{\circ} \mathrm{C}$ in a very short time as shown in Figure 5 . In order to evaluate the effect of primary airflow through the $\mathrm{CFB}$, the flow rate was 
varied and the system was stabilized before data was recorded. The emission and experimental data is being shown in Table 4.

Due to increased particle flow rate, the circulating particle forms dense bed. Palm shell particles fed to this layer get into contact with the high-temperature circulating particle and are quickly pyrolyzed. When palm shell particles (PSP) are in contact with a circulating particle at a higher temperature, the heat conductance to the PSP improves, and the PSP may be more quickly pyrolyzed. As shown in Table 4, as the primary airflow is increased, the $\mathrm{CO}$ concentration increased rapidly. This is probably due to very fine particle size and low residence time in the CFB furnace. This resulted in poor combustion and a high concentration of $\mathrm{CO}$ was found near the CFB top. The emission behaviour showed heavy white smoke representing incomplete and enhanced $\mathrm{CO}$ formation.

Table 4 Emission data for variation in primary air

\begin{tabular}{cccccc}
\hline No. & $\begin{array}{c}\text { Primary air } \\
\text { flow rate } \\
\mathbf{m}^{\mathbf{3}} / \mathbf{h r}\end{array}$ & $\begin{array}{c}\text { Exhaust } \\
\text { temperature } \\
{ }^{\circ} \mathbf{C}\end{array}$ & $\begin{array}{c}\mathbf{C O} \\
\mathbf{p p m}\end{array}$ & $\begin{array}{c}\text { NOx } \\
\mathbf{p p m}\end{array}$ & $\begin{array}{c}\mathbf{C F B} \text { top } \\
\text { temperature } \\
{ }^{\circ} \mathbf{C}\end{array}$ \\
\hline 1. & 1.0 & 185 & 2950 & 75 & 709 \\
2. & 1.5 & 160 & 4819 & 49 & 685 \\
3. & 2.0 & 150 & 7000 & 38 & 680 \\
\hline
\end{tabular}

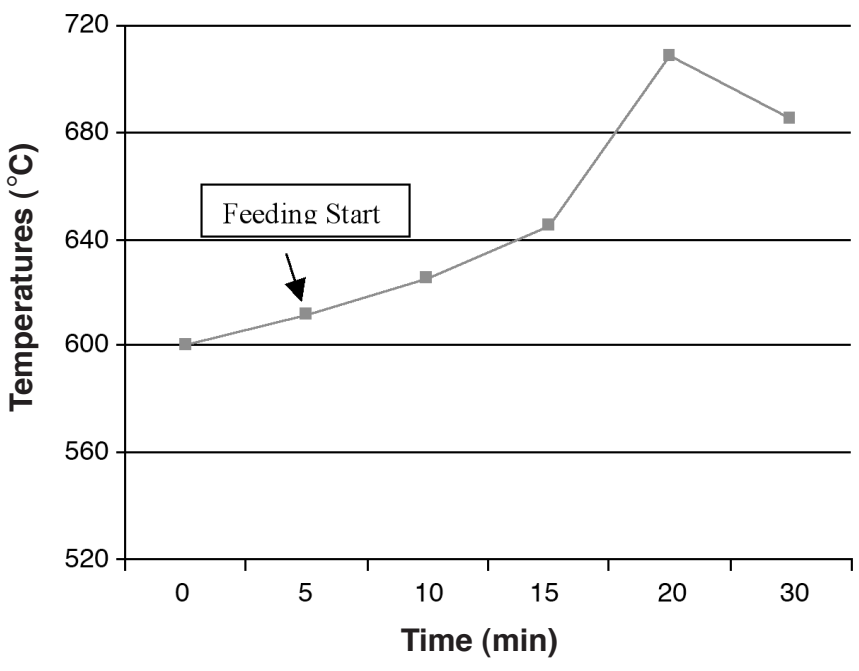

Figure 5 Variation of CFB temperature with time 


\subsection{CONCLUSIONS}

Based on the thermogravimetric analysis, pyrolytic temperature and heating rate were found to have significant influences on the pyrolysis of oil-palm shell. Kinetic parameters (activation energy and frequency factor) were obtained by curve fitting the experimental data. Using these kinetic parameters, a one-step global model was used to predict the pyrolytic conversion.

The gasification experiment was successfully conducted using the CFB test rig. As the result of gasification of oil palm shell waste, gas containing $\mathrm{H}_{2}, \mathrm{CO}$ and $\mathrm{CH}_{4}$ was produced. The dependence of in-furnace temperature and primary airflow on emissions was identified and knowledge was obtained about the relationship among them.

\section{ACKNOWLEDGEMENTS}

The author $(\mathrm{AH})$ would like to thank Malaysian Government Commonwealth Secretariat, Public Service Department Malaysia, Putrajaya for funding the $\mathrm{PhD}$ program. Thanks are due to Japanese Government and SIRIM Environment and Bioprocess Technology Centre for granting permission to use their CFB experimental facility.

\section{REFERENCES}

[1] http://econ.mpob.gov.my/economy/summaryindustry jan06.htm/. accessed on 20 March 2006.

[2] Ma, A. N., and A. Aminah. 1999. Status of Biomass energy in Malaysia. Malaysian Palm Oil Board (MPOB), Kuala Lumpur, Malaysia.

[3] Jamil, M. K., and F. N. Ani. 1999. Renewable Sources from Pyrolysis of Solid Wastes. Proceedings of the Malaysian Science E Technology Congress. Sarawak, Malaysia.

[4] Ani, F. N. 1992. Thermal Characteristics of Oil Palm Fruit Shells. Proceedings of the Second International Energy Conference- Energy from Biomass Residues. Kuala Lumpur, Malaysia.

[5] Bridgwater, A. V. and J. L. Kuester. 1988. Research in Thermochemical Biomass Conversion. London: Elsevier Science.

[6] Grassi, G., G. Gosse and G. Santos.1990. Biomass for Energy and Industry. London: Elsevier Science.

[7] Guo, J. and A. C. Lua. 2001. Kinetic Study on Pyrolytic Process of Oil Palm Solid Waste Using Two Step Consecutive Reaction Model. Biomass E Bioenergy. 20(2): 223-233. 